\title{
Comparative Study on Indonesian and Philippine Marine Exploitation and The Fish Consumption
}

\author{
Roche Christine C. Angeles ${ }^{1 *}$, Sharon Mendoza-Dreisbach ${ }^{2}$ \\ ${ }^{1}$ The Philippine Women's University Philippines, Philippina \\ ${ }^{2}$ Skyline University College United Arab Emirates, Arab
}

\section{A R T I C L E I N F O \\ Article history: \\ Received 22 June 2020 \\ Received in revised form 13 July 2020 \\ Accepted 18 August 2020 \\ Available online 01 \\ November 2020}

Keywords:

Marine Exploitation

Sustainable Development

\section{A B S T R A C T}

Indonesia and the Philippines are the two biggest archipelagic countries in the world spanning more than 25,000 islands. This made both states rich in marine natural resources and were considered to be the global centers of marine biodiversity. With the said availability of aquatic resources, both countries have also experienced the exploitation of these assets by people aiming to make profit from overfishing and illegal, unreported, and unregulated fishing practices. As such, the authors saw the merit of exploring the recently-implemented policies of both countries aiming to protect and preserve their marine natural resources. These were vital in assessing its effects on the human consumption of fisheries and triangulating the effectivity and efficiency of the said aquatic-related public policies. This study presented the concrete actions that both Indonesia and the Philippines took to battle illegal poaching by Chinese fishermen in the latter's waters, prevent the marine exploitation of fishing operations from the former, and the establishment of community-based marine preservations that gave permanent employment to its population and improved their way of living.

Copyright (C) Universitas Pendidikan Ganesha. All rights reserved.

\section{Introduction}

The Philippines comprises an archipelago of more than 7000 islands located in Southeast Asia. This makes the Philippines the fifth-largest island country in the world. The Philippines is divided and connected by water bodies making three land divisions: Luzon, Visayas, and Mindanao. The coastline of the Philippines is also one of the largest with 36,289 kilometers long. Also, the exclusive economic zone extends to 2,263,816 km², 200 nautical miles from its shore (Alesna et al., 2004; Guerrero III, 2011). With is in hand, the Philippines benefit from water in a huge aspect because of its archipelagic being. The Philippine waters extend around 2,000 kilometers from north to south with 184,600 kilometers of shelf area. The Philippines ranked among the major fish producing countries. One may note and distinguish the Philippines with rich marine biodiversity (Aliño, 2002; Pimentel, D., Berger, D., \& Filibirito, 2004)

In fact, the Philippines is one of the six countries that make up the "Coral Triangle". Indonesia on the other hand, is also an archipelagic state with 17,508 islands, with five island divisions: Sumatra, Java, Kalimantan, Sulawesi, and Papua (Benavente-Villena \& Pido, 2004; Firmansyah et al., 2019). Indonesia has 93,000 square kilometers of inland seas (Yunanto et al., 2019). With this, Indonesia has a large amount of protein supply from fish and seafood which became a major commodity to the country. Being part of the Coral Triangle where the world's coral reef fishes reside, the Philippines and Indonesia both share marine sentiment and weight. However, both countries' marine life is under the threat of marine resource exploitation, especially fisheries.

What makes the Philippines and Indonesia very similar to each other is fish consumption. Being archipelagic states, both countries have access to the sea and have every opportunity to make it a part of livelihood and play a big role in human consumption. The Philippines' fishery agriculture has employed many fishermen and has become a source of income, especially those who live by the shore. Philippine marine fisheries are important in the industry (Barclay, 2012; Gutti et al., 2012). It provides and 
completes the food requirements of the population. This is because fish provides vitamins and minerals, promote a healthy lifestyle, and fight illnesses that humans may incur. The nutritional guidelines of Filipinos consist of consuming fish, lean meat, poultry, and dried beans. Also, there is a recommended intake of fish and fish products, also called "Pinggang Pinoy" which refers to the health food plate that Filipinos should follow. Pinggang Pinoy also promotes "Go, Grow, and Glow", where fish is under the Grow category. 'Grow' primarily include Fish consumption. Where, eating fish is essential for muscular growth and obtaining fatty acids from fish that protect against heart diseases and for child brain development (Barclay \& Kinch, 2013; Mccormack \& Barclay, 2013). The Philippines has a variety of fish products to support the fish requirement of a healthy diet: Fresh fish, dried fish, processed fish, and crustaceans, and mollusks. These then are cooked in different types of dishes for Filipinos to enjoy. Fisheries play a big role in achieving a healthy lifestyle. Indonesia, on the other hand, has the highest fishery production in Southeast Asia, superior to other Southeast Asian countries, including the Philippines. With similar reasons with the Philippines, Indonesia also lives off of Fish. However, fish consumption in Indonesia is lower despite its large production (Beamish et al., 2006; Firmansyah et al., 2019).

This study presented the concrete actions that both Indonesia and the Philippines took to battle illegal poaching by Chinese fishermen in the latter's waters, prevent the marine exploitation of fishing operations from the former, and the establishment of community-based marine preservations that gave permanent employment to its population and improved their way of living.

\section{Methods}

To comparatively analyze the similarities, differences, and learning experiences of both Indonesian and Philippine marine policies, this study employed the qualitative research method of document triangulation on the existing academic literature, statutes, legislations, and jurisprudence that constitute relevant data in public policy analysis.

Among qualitative research methods applied in public policy analysis, triangulation is one of the novelist techniques in deciphering issues in the sustainability of international and domestic public policies (Roe, 2013). Triangulation converges the following four major policy questions to come up with a sound and scientific decision-making process, namely: (1) What is sustainable development? (2) Why is it an issue? (3) What needs to be done? and, (4) What can actually be done? Moreover, document triangulation may also be utilized to decipher the dynamics of public policies, including that of marine protection legislations, and measure its impact on the community, social, and national development (Rutherford et al., 2010).

\section{Results and Discussions}

\section{Importance of Fisheries: Fish Consumption}

There are several reasons behind the low fish consumption in Indonesia. First, the infrastructure needed to distribute high-quality fish is lacking. High-quality fish must be treated well under accommodating infrastructure with cold storage. However, Indonesia does not have this. Thus, the quality of fish is compromised and affecting the market. Second, types of fish caught in Indonesia such as tuna, shrimp, octopus, etc. are more marketed internationally. High-quality fish are mostly given to international markets. The local markets and consumers, then, are exposed to lower quality of fish (FAO, 2020). Lastly, the people's preference in Indonesia, despite knowing the health benefits of fish, still prefer consuming meat and other dairy products (Ariani et al., 2018). With this, an intensive program was implemented to balance the differences, promote other fish industries, and at the same time promote healthy living through fish in Indonesia. The program "Gemarikan", which means "Eating Fish Movement" or "Enjoy Eating Fish" was pushed by the Ministry of Marine Affairs and Fisheries, in an attempt to heighten the fish consumption of the Indonesian households. This program aims to increase the consumption of fish of the Indonesians, to improve the quality of life of its people (Firmansyah et al., 2019). The program also displays the competency of fisheries in the country. This pushes for the preservation of fish and the input and output of fisheries. Fish caught from Indonesia are consumed in dried, salted, boiled, or fermented form, while others consume it fresh. Similar to the Philippines, Indonesia also includes fish in their primary diet. Similar to 'Pinggang Pinoy', Indonesia also has a nutritional diet requirement which they call "Balanced Nutrition Guidelines" wherein food intake and a healthy lifestyle are indicated altogether. Fish is consumed in many ways to fit into the Indonesian nutritional requirements. Indonesian food requirements are displayed in a rounded pyramid. In their plan, fish is the third tier indicating that fish has to be taken in 2-4 portions in different kinds (FAO, 2015). 
This shows the development of the promotion of the benefits of fish-eating and promotion of fish markets, as well.

Primarily, fisheries both in the Philippines and Indonesia are strengthened by human consumption. Although however, Indonesia may be lagging behind on this factor, they remain at the top in fish production because to market its product internationally. With this one hand, the government of Indonesia recognized it and implemented a program and further promotion of fish consumption. While in the Philippines, Fish is a very important part of the meal that Filipinos consume regularly. The Philippines are one of the countries whose fishery products are on a high intake (FAO, 2015). The two countries may have a different approach in promoting the fishery industry, both have the urge to increase both consumption and the improvement of an economy based on fisheries. However, there are challenges in trying to fulfill its goals and purposes; threats that face the efforts of marine life and fisheries enrichment.

\section{Marine Exploitation}

Despite the success of fisheries in the Philippines and Indonesia, both face the problem of marine exploitation, especially on fisheries. Some cases affect marine biodiversity and the health of its organisms. Some threats would be present in the long-time run. However, people tend to oversee it because of their economic stand. Climate change, IUU, and overfishing are the threats that the marine health of the Philippines and Indonesia face (Guerrero III, 2011).

\section{Overfishing}

Overfishing is described as taking sea wildlife at a large rate that would not balance or replace the species caught. In simple terms, catching fish more than what the fish can replenish. This, then, disrupts food chain and loss of habitat (Beamish et al., 2006). The damage goes beyond the environment. It can also direct humans especially those who rely on fish for protein. What pushes fisheries to overfish are caused by advances in the fishing industry, with their efficient and high-performance devices, catching fish on a larger catch, more than what is normal became possible. This was used to generate more fish that will be sold in the market (Valk \& Srinivasan, 2011). The abundance of marine life and fishery in the Philippines is the primary reason why overfishing took place. Fishermen are only allowed to capture mature fishes. But, they chose to exploit marine life and catch fish from young to adult (Flores, 2004). Also, the Philippines are performing illegal methods of catching fish such as muro-ami or the drive-in net, wherein a gear with a movable magnet and two detachable wings, is spread in reefs, then fishermen will drive the fish towards the magnet then catch the fish; Kayakas or ring net is the smaller version of muro-ami; explosives- the use of dynamite to destroy coral reefs and kill fish so that fish would come up; poisonous substances like cyanide, are used to kill or disable fish and eradicate predators in fishponds. However, this shall be performed within acceptable limits; lastly, electrofishing. It is a method wherein the use of electric generators to kill or disable fish. All above are used to easily catch fish, without consideration of its consequences both environmentally and for human consumption (FAO, 2015). Indonesia on the other hand is fonder of dynamite fishing, similar to the Philippines' Muro-ami. Indonesia calls this blast fishing. For the same reasons, Indonesia overfishes to cater to the demands of the market, disregarding whether the method of acquiring used is dangerous and illegal. Explosives do not only ruin corals and marine life but also damages the quality of water in the long run. Pollutant accumulation is one of the serious effects that Indonesia can predict. What urges overfishing is the demand in the market and the attempt of both countries to produce mass fish to increase its availability. Engaging in different methods then are unstoppable despite its adverse effect, especially in the long run.

\section{Illegal, Unreported and Unregulated Fishing (IUU)}

Illegal fishing is a key reason for overfishing. It affects the quantity of fish in the sea, their health, and it also poses an effect in food security and stability and puts it at risk (Case et al., 2007). IUU causes imbalances in the fishing scene. This includes breaking laws and regulations concerning fishing. Examples are fishing without a license, fishing in a closed area, fishing using prohibited methods, overfishing (Eriksson et al., 2019). Illegal fishing technically is fishing under the jurisdiction of another state without permission. Unreported fishing, on the other hand, is fishing without reporting or misreported to a relevant authority that follows certain laws and principles. Lastly, Unregulated fishing occurs in areas with no management measures in fishing and conducted in a manner contradicting state responsibility. Fishing vessels without flags are also under this category. IUU creates a setback in achieving long-term sustainability under fishing responsibilities. This creates disadvantages in stocks, marine biodiversity, and food security of the consumers. This also affects the decline of fish stocks which would result in finding alternatives, usually far from the usual (FAO, 2016). In 2019, the Philippines lost around P68 billion annually to IUU according to the US Agency for International Development (USAID). The US government 
launched the Fish Right project. This addresses marine life governance and the weight of fish in the Philippine waters for marine protection and sustainable fisheries so that IUU will be diminished. While Indonesia's approach towards IUU was in cooperation with the Ministry of Marine Affairs and Fisheries. This was an effort towards a three-year plan in technical assistance to address the current needs of the fishing industry (FAO, 2020). States make effort to reduce or eliminate IUU's for the economic state of the industry, but also the safety of fish and other underwater organisms to be caught.

\section{Effects on Humans}

Marine Exploitation does not stop its effect on the environment. Consumers, humans, are also deeply affected by the phenomena. The disruption of the food chain will be the one at stake. With unbalanced water properties, unhealthy living organisms, and other effects of marine pollution, the health of the people will be compromised. Unhealthy fisheries would result in unhealthy consumers. Many water bodies are now polluted, resulting in the death of aquatic animals and the disruption of the food chain. With the unbalanced marine life, humans would have to deal with alternatives or worst-case scenario, remove fish from the diet plan. Fish has proven its worth to the consumers and has a promising role in a healthy protein diet. Fisheries have been a huge source of food and livelihood. However, as the population grows, the demand gets higher, but the fisheries could not keep up because of environmental incapacities caused by marine exploitation. The problem that would occur here are the diet plans of both the Philippines and Indonesia have, wherein they share a similar need for fish products (Barclay \& Kinch, 2013). The deterioration of the quality of fish could be caused by marine fisheries trying to cater to the needs of the human diet and consumption. All catches will be out in the market, without quality control, so that it would meet the demand. Thus, this is inviting chaos between man and nature (Thompson \& Subasinghe, 2011). Being said, the risk of consuming contaminated fish is high. Wherein, if taken for a long time, would cause health problems such as hormonal issues, reproductive issues, and damage to nervous systems and kidneys. It would then contradict the purpose of eating fish and including it as essential for healthy living.

\section{Actions Toward Fisheries Improvement and Conservation Philippine actions on marine conservation and quality of life}

In the profiling done by the Bureau of Fisheries and Aquatic Resources (BFAR) of the status of Philippine fisheries, they mentioned that the current situation of our waters is at critical times in Philippine coastal resources (Khalili Tilami \& Sampels, 2017; Luna et al., 2003). For the sustainable development of our marine frontier, high priority should be given it by the government considering that it can provide valuable social, economic and environmental benefits to the present and future generations of Filipinos if it is rationally and efficiently managed (Guerrero III, 2011) ." The role of the national government agencies is vital in ensuring the protection of marine resources and the quality of life of the Filipino people. To present the concrete measures that the Philippine authorities took in protecting both marine and human life, the following table shows the key legislations that mandated BFAR to enforce regulations on this matter (Jatulan, 2004).

Table 1. Fisheries-Related Philippine Legislation

\begin{tabular}{|c|c|c|}
\hline Year & Legislation & Feature(s) \\
\hline 1963 & RA 3512 & Created the Philippine Fisheries Commission. \\
\hline 1975 & PD 704 & BFAR's mandates included development and management of the country's fisheries. \\
\hline \multirow[t]{2}{*}{1984} & EO 967 & Administration of BFAR was transferred from Department of Natural Resources (DNR) to \\
\hline & & $\begin{array}{l}\text { Ministry of Agriculture and Fisheries (some functions, such as those related to the management } \\
\text { of coastal and marine habitats remained with DNR). }\end{array}$ \\
\hline 1986 & EO 116 & $\begin{array}{l}\text { BFAR was relegated to the food production group of DA and became a staff bureau. BFAR's } \\
\text { administrative, regulatory and enforcement functions and field units were abolished. }\end{array}$ \\
\hline 1987 & EO 292 & Both DA and DENR were assigned fisheries-related functions. \\
\hline 1991 & RA 7160 & Specific fishery management functions (regulatory and enforcement) were devolved to LGUs. \\
\hline 1997 & RA 8435 & Agriculture and Fisheries Modernization Act. \\
\hline 1998 & RA 8550 & BFAR was reconstituted as a line bureau of DA. \\
\hline
\end{tabular}


Beyond coastal resources management, BFAR is also tasked with regulating commercial fishing operations, which includes licensing (Alesna et al., 2004) and ensuring that there are people-oriented policies within fishing communities that can help generate income for their respective populations (Flores, 2004). Moreover, the government agency has long been recording the cases of poaching by Chinese fishermen in the high seas of Palawan that are part of our exclusive economic zone (BenaventeVillena \& Pido, 2004). Moreover, marine science experts from the University of the Philippines have recently recommended opportunities for research on aquatic resources management that could help attract marine life and increase fishing production again in the country (Onda et al., 2020). These include science-based decision making in environmental issues such as plastics pollution in our waters and climate-related changes that affect our marine life.

\section{Indonesian actions on marine conservation and quality of life}

In 2007, the government of the Republic of Indonesia implemented four legislations that officially established marine protected areas (MPAs) in the archipelago. Before the enactment of the said laws, the country's Ministry of Fisheries and Marine Affairs was already mandated by the sitting government to develop and manage the highlighted MPAs below so that it can sustain marine fisheries (Wiadnaya et al., 2011). Impact research from the primary data provided by the Indonesian marine ministry and the Indonesia Statistic Center Agency revealed that since the establishment of MPAs, areas included in the said regions had a lower fishing index (Yunanto et al., 2019). In layman's terms, having marine protected areas prevented high seas fishermen from overexploiting their fishing operations.

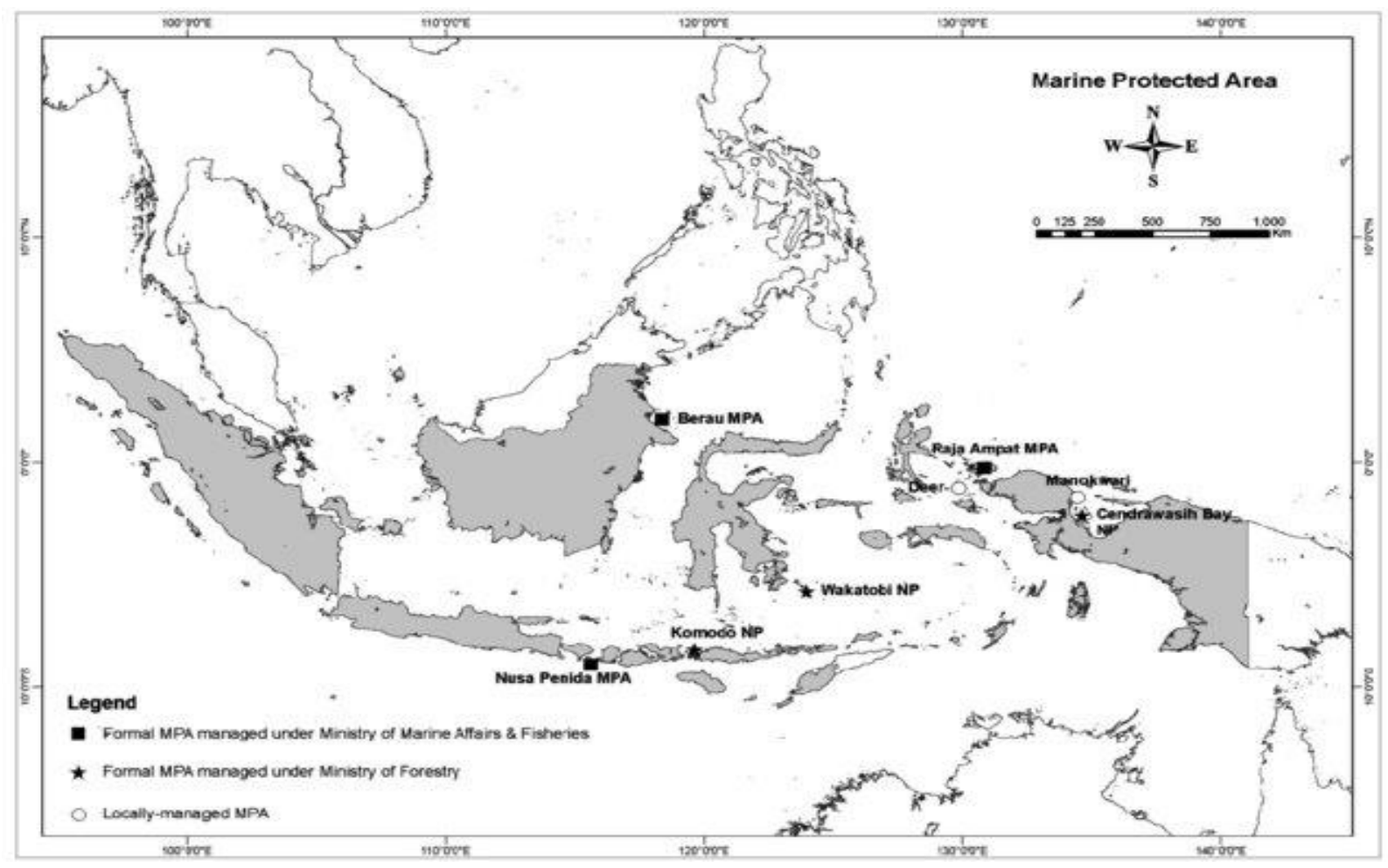

Figur 1. Marine Protected Areas in Indonesia

The Ecosystem Approach to Fisheries implemented by the Indonesian government in 2010 established indicators that form the basis in regulating the operations of fishermen in the country (Hutubessy \& Mosse, 2015). Among the indicators include fish size, juvenile caught proportion, and species composition. To balance fishing activities, authorities suggested that an alternative fishing approach management could be catching one fish species at a given time to ensure the sustainable growth of other marine species.

Recent research on the economic standings of fishermen in MPAs revealed that fishing-related income decreased among fishermen due to conservation efforts done by the Indonesian government. This made coastal communities residents accept the alternative livelihoods provided by the authorities such as guarding the marine protected areas against potential overfishing done by other fishing operations in the area. This made the communities directly on conservation efforts. Upon observing that they had improved 
economic situations since taking working for the MPAs, they took the initiative to do information campaigns about the efforts of the government to sustainably protect marine life in the country (Eriksson et al., 2019).

\section{Conclusion}

Lessons that could be learned from phenomena like this would all go down to the conservation of the environment and natural resources. Resources, like water, should always be taken into consideration because it would create a great impact over time. Learning that fish consumption is huge in archipelagic countries, like the Philippines and Indonesia, fisheries and other marine species shall be taken care of and be under plans that would regulate its healthy state. Governments, organizations, as well as fishermen, should be involved in precautionary and remedial measures that can minimize ill effects of natural resources exploitation. Boundaries should be set clear for both sides to be able to enrich one's health and protect the environment. Fisheries play a big role in providing food, thus it should never be taken for granted. Global warming, water quality, and overfishing should be addressed well and be acknowledged, to prevent and control its adverse effects.

\section{References}

Alesna, E. B., Dizon-Corrales, \& Cabangbang, J. Q. (2004). Commercial fisheries licensing system. DABFAR (Department of Agriculture-Bureau of Fisheries and Aquatic Resources).

Aliño, P. M. (2002). An overview of Philippine fisheries [Marine Science Institute, University of the Philippines, Quezon City]. http://innri.unuftp.is/pdf/Philippine Fisheries.pdf

Ariani, M., Suryana, A., Suhartini, S. H., \& Saliem, H. P. (2018). Keragaan Konsumsi Pangan Hewani Berdasarkan Wilayah dan Pendapatan di Tingkat Rumah Tangga. Analisis Kebijakan Pertanian, 16(2), 147-163. https://doi.org/10.21082/akp.v16n2.2018.147-163

Barclay, K. (2012). The Social in Assessing for Sustainability : Fisheries in Australia. Cosmopolitan Civil $\begin{array}{lllll}\text { Societies: } \quad \text { An } & \text { Interdisciplinary }\end{array}$ https://epress.lib.uts.edu.au/index.php/mcs/article/view/2655

Barclay, K., \& Kinch, J. (2013). Local Capitalisms and Sustainability in Coastal Fisheries: Cases from Papua New Guinea and Solomon Islands. Emerald Group Publishing Limited.

Beamish, R., McFarlane, G., \& Benson, A. (2006). Longevity overfishing. Progress in Oceanography, 68(2), 289-302. https://doi.org/10.1016/j.pocean.2006.02.005

Benavente-Villena, A. B., \& Pido, M. D. (2004). Poaching in Philippine marine waters: intrusion of Chinese fishing vessels in Palawan waters. In In turbulent seas: the status of Philippine marine fisheries (pp. 265-268). Coastal Resource Management Project.

Case, M., Ardiansyah, F., \& Spector, E. (2007). Climate Change in Indonesia: Implications for Humans and Nature. Worldwide Wildlife $\quad$ Fund, 1. https://wwfeu.awsassets.panda.org/downloads/inodesian_climate_change_impacts_report_14nov 07.pdf

Eriksson, B., Johansson, F., \& Blicharska, M. (2019). Socio-economic impacts of marine conservation efforts in three Indonesian fishing communities. Marine Policy, 103(1), 59-67. https://doi.org/10.1016/j.marpol.2019.02.007

FAO. (2015). The Consumption of Fish and Fish Products in the Asia-Pacific Region based on Household Surveys. Food and Agriculture Organization of the United Nations. http://www.fao.org/3/ai5151e.pdf

FAO. (2016). The Consumption of Fish and Fish Products in the Asia-Pacific Region based on Household Surveys. Food and Agriculture Organization of the United Nations.

FAO. (2020). Fisheries \& Aquaculture - Country Profile. Food and Agriculture Organization of the United Nations. http://www.fao.org/fishery/facp/IDN/en

Firmansyah, Oktavilia, S., Prayogi, R., \& Abdulah, R. (2019). Indonesian fish consumption: an analysis of dynamic panel regression model. IOP Conference Series: Earth and Environmental Science, 246(1). https://doi.org/10.1088/1755-1315/246/1/012005 
Flores, M. M. M. (2004). Olango birds and seascape tour: A people-oriented ecotourism venture. In In Turbulent Seas: The Status of Philippine Marine Fisheries. DABFAR (Department of AgricultureBureau of Fisheries and Aquatic Resources).

Guerrero III, R. D. (2011). Managing Our Marine Frontier: Challenges and Opportunities. The National Academy Of Science And Technology, Philippines.

Gutti, B., Aji, M. M., \& Magaji, G. (2012). Environmental impact of natural resources exploitation in Nigeria and the way forward. Journal of Applied Technology in Environmental Sanitation, 2(2), 95-102. http://trisanita.org/jates/atespaper2

Hutubessy, B., \& Mosse, J. (2015). Ecosystem Approach to Fisheries Management in Indonesia: Review on Indicators and Reference Values. Procedia Environmental Sciences, 23, 148-156. https://doi.org/10.1016/j.proenv.2015.01.023

Jatulan, W. P. (2004). The evolving role of national government agencies in coastal and fisheries management. In In Turbulent Seas: The Status of Philippine Marine Fisheries (pp. 175-179). DABFAR (Department of Agriculture-Bureau of Fisheries and Aquatic Resources).

Khalili Tilami, S., \& Sampels, S. (2017). Nutritional Value of Fish: Lipids, Proteins, Vitamins, and Minerals. Reviews in Fisheries Science \& Aquaculture, 26(2), 243-253. https://doi.org/10.1080/23308249.2017.1399104

Luna, C. Z., Silvestre, G. T., Green, S. J., Carreon, M. F., \& White, A. T. (2003). Profiling the Status of Philippine Marine Fisheries: A General Introduction and Overview. In In Turbulent Seas: The Status of Philippine Marine Fisheries (pp. 3-13). DABFAR (Department of Agriculture-Bureau of Fisheries and Aquatic Resources).

Mccormack, F., \& Barclay, K. (2013). Engaging with Capitalism: Cases from Oceania. Research in Economic Anthropology, 33, 107-138. https://doi.org/10.1108/S0190-1281(2013)0000033007

Onda, D. F. L., Gomez, N. C. F., Purganan, D. J. E., Tolentino, M. P. S., Bitalac, J. M. S., Calpito, J. V. M., \& Viernes, A. C. A. (2020). Marine Microbes and Plastic Debris: Research Status and Opportunities in the Philippines. Philippine Journal of Science, 149(1), 71-82. http://philjournalsci.dost.gov.ph/images/pdf/pjs_pdf/vol149no1/marine_microbes_and_plastic_de bris_.pdf

Pimentel, D., Berger, D., \& Filibirito, D. (2004). Water Resources: Agricultural and Environmental Issues. Bioscience, 54(2). https://doi.org/10.1641/0006-3568(2004)054[0909:WRAAEI]2.0.CO;2

Roe, E. (2013). Taking Complexity Seriously Policy Analysis, Triangulation and Sustainable Development. Springer Verlag. https://doi.org/10.1007/978-1-4615-5497-4

Rutherford, G. W., McFarland, W., Spindler, H., White, K., Patel, S. V., Aberle-Grasse, J., Sabin, K., Smith, N., Tache, S., Calleja-Garcia, J. M., \& Stoneburner, R. L. (2010). Public health triangulation: approach and application to synthesizing data to understand national and local HIV epidemics. BMC Public Health, 10, 447. https://doi.org/10.1186/1471-2458-10-447

Thompson, B., \& Subasinghe, R. (2011). Aquaculture's role in improving food and nutrition security. Food and Agriculture Organization of the United Nations.

Valk, R., \& Srinivasan, V. (2011). Work-Family Balance of Indian Women Software Professionals: A Qualitative Study. IIMB Management Review, 23(1). https://doi.org/10.1016/j.iimb.2011.01.006

Wiadnaya, D., Syafaat, R., Susilo, E., \& Setyohadi, D. (2011). Recent Development of Marine Protected Areas (MPAs) in Indonesia: Policies and Governance. Journal of Applied Environmental And Biological Sciences, 1(12), 608-613.

Yunanto, A., Halimatussadiah, A., \& Zakaria, N. (2019). The impact of MPA establishment on fish extraction in Indonesia. IOP Conference Series: Earth and Environmental Science, 241. https://doi.org/10.1088/1755-1315/241/1/012013 